$$
\text { 川口 尊 三*·栗 山 和 } \text { 益 }^{* 2}
$$

\title{
The Relation between Fine Ratio and Particle Size of Sinter Product in Sinter Cake Sizing Process
}

Takazo KAWAGUCHI and Kazuyoshi KURIYAMA

\begin{abstract}
Synopsis :
The breakage process of sinter cake was investigated to find the most efficient sizing method that minimizes the $-5 \mathrm{~mm}$ fraction in crushed cakes. Sinter cakes with various initial sizes were crushed with a jaw-crusher, shatter and tumble testers to compare the $-5 \mathrm{~mm}$ fines generation processes. The results showed that the dominant factor that decides the amount of $-5 \mathrm{~mm}$ fines is the final size of the crushed +5 mm products. Under a specific crushing mode, the $-5 \mathrm{~mm}$ fines mass is decided by the mean particle size of the residual $+5 \mathrm{~mm}$ products, independent of the cake strength. The second dominant factor is the crushing mode and the jaw-crusher yields the least $-5 \mathrm{~mm}$ fines mass among the three crushing modes. Thus the most efficient process is to crush sinter cake with jaw-crushers to a size which is small enough as a feed for blast furnaces. The reason why a jaw-crusher yields the least $-5 \mathrm{~mm}$ fines mass was considered to be due to a volume breakage included in this mode where the applied energy is used for the size reduction, while the other breakage mode, surface breakage is not preferable to crush sinter cakes because the size reduction takes place by surface grinding that leads to a high $-5 \mathrm{~mm}$ fines mass.

Key words : sintering process; particle size; crushing; surface breakage; volume breakage ; crushing mode ; yield.
\end{abstract}

\section{1. 緒言}

鉄鉱石焼結釷製造プロセスは脆性度の高い焼結ケーキ を破砕整粒することによって成品を得ており, 成品歩留 の低いプロセスである。このため, その要因調査と改善 対策が数多く実施されているが，これらは焼成不完全部 の低減, 焼結ケーキ強度の向上, 搬送過程の粉化低減お よび成品の回収装置(篩)の改善に関するものが多く, 焼 結ケーキの破砕に関するものが少ない。これは焼結ケー キからの粉発生現象に関し本質的解析がまだ十分でな く, さらにその具体的改善策が難しいためと思われる. 従来, 破砕および粉化に対する強度解析は高炉に装入 される成品焼結鉱を対象としていたが, 最近ではその母 体である焼結ケーキも対象とされるようになり，焼結 ケーキの空隙構造解析も含めその破砕現象を基本的な面 から把握しようとする研究 ${ }^{1)-4)}$ が行われている.これ
らの研究が進めば従来から蓄積された成品強度に関する 知見 ${ }^{5) 6)}$ と組合せて，ケーキから最終成品までの全破砕 現象が明らかとなり, 高成品歩留を得るための焼結ケー キ空隙構造およびその成品処理方法の指針が得られるも のと期待される.

本報では焼結ケーキから最終目標粒径の焼結鉱に至る までの全体的な破砕現象に関し成品粒径と発生粉率との 関係について検討するとともに，実用上最も重要な点で ある「焼結ケーキを高炉が要求する粒径までいかに粉発 生の少ない状態で破砕するか」について考察を行った。

\section{2. 焼結ケーキ破砕基礎実験}

\section{$2 \cdot 1$ 実験方法}

\section{$2 \cdot 1 \cdot 1$ 破砕供試料}

粉発生現象に対する支配的要因を抽出するため,ヶー キ空隙構造および形状，寸法を変化させた試料を製造し

平成 3 年 10 月 31 日受付 平成 4 年 4 月 10 日受理（Received on Oct. 31, 1991; Accepted on Apr. 10, 1992)

* 住友金属工業(株)鉄鋼技術研究所 工博 (Iron \& Steel Research Laboratories, Sumitomo Metal Industries, Ltd., 16-1 Oaza-Sunayama Hasakimachi Kashima-gun Ibaraki pref. 314)

*2 住友金属工業(株)未来技術研究所 (Advanced Technologies Research Laboratories, Sumitomo Metal Industries, Ltd.) 
破砕実験を実施した. さらに破砕方法の変更および破砕 条件選定のための予備実験も実施した。

ケーキ空隍構造の異なる試料は焼結原料のコークス配 今量を $2.5 \%$ ～ $3.7 \%$ に変更し，広く普及している標準 焼綪鍋（㨁径 $300 \mathrm{~mm}$ ）を用い実機操業実績に近い原料 層厚 $500 \mathrm{~mm}$ の一定条件で焼成を行い製造した。形状变 更は鍋形状を円柱から直方体に変更することによって, また寸法変更は円柱形では $300 \mathrm{~mm}$ 㨁径で層厚を 100 $\mathrm{mm} \sim 700 \mathrm{~mm}$ に, 直方体では層厚 $300 \mathrm{~mm}$ で横幅を 100 $\mathrm{mm} \sim 400 \mathrm{~mm}$ に変更することによって操作し，鍋側壁部 からの放熱も考虑して実機操業実績値よりやや高い $3.4 \%$ のコークス量でケーキを製造した。これら形状お よび寸法の変更条件を Fig. 1 にまとめる.

また破砕条件に関する予備実験および破砕方法を変更 する実験ではコークス量 $3.4 \%$ ，直径 $300 \mathrm{~mm}$ の円柱鍋 を用い, 前者は原料層厚 $500 \mathrm{~mm}$, 後者は原料層厚 700 $\mathrm{mm}$ の一定条件で焼成ケーキを製造しこれを用いた。

鍋焼成においては, 焼成風速差に起因する層内温度差 の焼結ケーキへの影響を極力小さくするため, 鍋空筒風 速が常に一定 (標準状態で $17.0 \mathrm{~m} / \mathrm{min}$ ) となるよう制御 した. 原料は実機ラインで配今されコークス添加直前で 採取された原料の混命粉（T. $\mathrm{Fe}=51.1 \%, \mathrm{SiO}_{2}=4.8 \%$, $\mathrm{A}_{2} \mathrm{O}_{3}=1.7 \%, \mathrm{CaO}=9.6 \%$,フリーカーボン $\left.=0.4 \%\right)$ を用いた.

鍋焼成し排出された焼成物には一部焼成不完全部分 (末焼結部分)が混在するので，焼結ケーキ破砕における 粉発生を調査する外乱となる。そこで予備実験結果(後 述）を基に焼成不完全部分を除去するため，鍋焼成物を 落下強度試験機（JIS-M8711-1987）で 1 回落下後, 5 $\mathrm{mm}$ 穊で分級し篩上產物を焼結ヶーキの供試料とした。

直方体供試料にあっては試料間及び試料内の焼結ケー キ空隙構造を出来るだけ均一にするため, 鍋側壁部に断 熱ボードを用いるとともに，焼成温度の低い上層表面か ら $100 \mathrm{~mm}$ 部分 (Fig. 1 の破線より上部)を削除した。

$2 \cdot 1 \cdot 2$ 破砕方法および条件

焼結ケーキの破砕には落下強度試験機, 回転強度試験

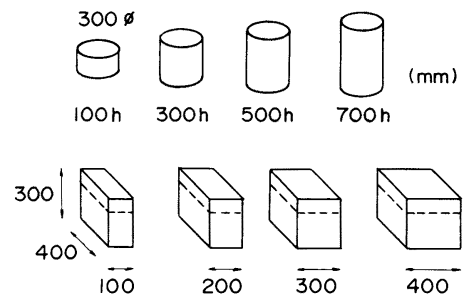

Fig. 1. Size and shape of examined sinter cakes. (The tops of the triagonal cakes denoted by the dotted lines were removed before breakage tests.)
機 (JIS-M8712-1987)，シングルトグル型ジョークラッ シャー(横幅 $450 \mathrm{~mm}$, 入口歯幅 $300 \mathrm{~mm}$, 高さ $530 \mathrm{~mm}$ ) を用いた。落下強度試験機および回転強度試験機におい ては,その積算落下回数 $(4,8,16,32,64$ 回)や積算回 転数（10,20,50,150 回）を变更して焼結鉱成品粒子の 粒径, 粒子表面形状, 気孔率および粉率を測尘した。 ジョークラッシャーは口で物を噛むように周是顎と往復 顎との間に塊状の破砕物を挟んで強大な压力で压し砕く 破砕機 ${ }^{7)}$ であるが, 破砕条件として出口菌幅 $(35,45$, $50,55 \mathrm{~mm}$ ）を変更し 1 パスで試料を破砕し，成品粒径 および粉率を測定した。

そして 3 種類の破砕機による破砕方法の違い, すな わち落下衝撃 (落下強度試験機), 回転摩耗 (回転強度 試験機), 層圧縮圧力破砕 (ジョークラッシャー)の違 いに対する破砕焼結ケーキの成品粒度分布と粉発生量の 関係について比較した。

なお, ジョークラッシャーにおける破砕は破砕物が破 砕部から直に除外される自由粉砕 であるのに対して, 落下強度試験機および回転強度試験機による破砕におい ては破砕物が系内に留まる閉塞破砕 'なので，破砕処理 過程で発生する粉の存在およびその供試料量の違いよる 破砕結果への影響が考えられる。そこで尒備実験結果に 基づき，本実験では破砕供試料量を一定に定めず +5 $\mathrm{mm}$ の試料全量を一度に破砕処理するとともに, 所定落 下回数または回転数毎に試料を取り出し，篩分級処理を 行い粒度分布を測定した後， $-5 \mathrm{~mm}$ 粉試料を除去した $+5 \mathrm{~mm}$ 試料だけを再度強度試験機にもどして累積的に 落下または回転衝撃を加え評価した。

粒度測定は $5,10,25,50,75,100 \mathrm{~mm}$ の打抜き鋼鉄角 孔篩を用い, 平均粒径は体積基準により算出した。また, ここでは成品は $5 \mathrm{~mm}$ 以上の試料とし，粉は $5 \mathrm{~mm}$ 以下 の試料と定義した.

$2 \cdot 1 \cdot 3$ 焼結鉱成品粒子の表面形状と気孔率の測定

13〜15 mm の成品焼結鉱を樹脂に埋め込み，切断面 を粒子実体部と気孔空隙部とに識別し画像定量処理装置 によりマクロ気孔率，および粒子断面外㓮長 $(L 1) \mathrm{mm}$ を求めた。さらに粒子を凸体やとみなした場合の粒子断 面積 $(S) \mathrm{mm}^{2}$ および粒子断面外周長 $(L 2) \mathrm{mm}$ を測定 し, 粒子表面凹凸度 $=L 1 / L 2$ および凸体の円形度 ${ }^{\dagger 2}=$ $\sqrt{4 \pi S} / L 2$ を求めた. (後掲 Fig. 7 参照)この場合のマ クロ気孔率は径が $1.5 \mathrm{~mm}$ 以上のものである. また別途, $19 \sim 21 \mathrm{~mm}$ 焼結鉱粒子 (Fig. 2 に示される斜線部)

\footnotetext{
†物体内部に2つの点を任意にとった時，2点を結ぶ線分が常にこの 物体内部にある物体を凸、体という。

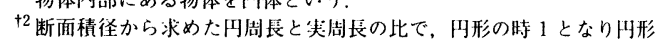
から遠ざかると倠が小となる.
} 


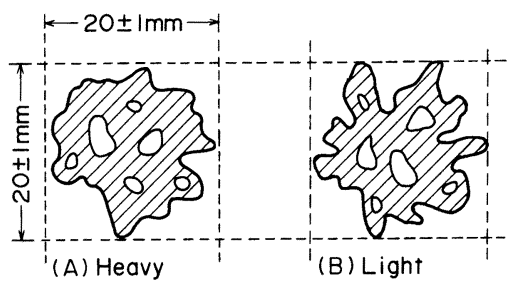

Fig. 2. The schematic descrptions of irregularities on surface of sinter product. (The light particle (B) has more ups and downs on the surface than the heavy one (A) on 19-21 mm particle.)

の見掛密度と密度を測定 (JIS-M8716-1987, JIS-M87171987）しミクロ気孔率を求めた。この場令のミクロ気孔 率は径が $0.5 \mathrm{~mm}$ 以下のものである

成品焼結鉱の粒子表酎形状（山凸）については画像処 理法とは別に試料を篩目差の小さい 2 枚の角孔篩（19 $\mathrm{mm}$ と $21 \mathrm{~mm}$ )を用い, 所定篩粒径の焼結鉱だけを取り 出しその質量と橭数を測定し, 所定粒径焼結鉱 1 個あ たりの平均質量を求める方法も検討した，測定焼結鉱粒 子の均斉度（凸体とみなした時の円形度と対応）および 見掛密度の差が小さくまた粒径を狭い範囲に規定すれ， ば, 粒子平均質量は粒子表面形状を反映する.すなわち, Fig. 2 に見られるように質量の小さい粒子ほど粒子表面 山凸が大きい。

なお，調査サンプル採取にともなう破砕実験結果への 影響を小さくするため, 調査粒度は存在個数の多い粒度 範网を選ぶとともに樹脂埋め巡み試料と密度測定試料と で異ならせ，サンプル採取量を極力少なくした．

\section{$2 \cdot 1 \cdot 4$ 実験方法に関する予備実験}

$2 \cdot 1 \cdot 1$ で述べたように，焼結ケーキに関する破砕の検 討では事前に不完全な焼成部分を除去しておく必要があ る。そこで、円柱鍋焼成物を落下強度試験機によって破 砕処理を行い，未焼結部に残存するフリーカーボンおよ びフリー $\mathrm{CaO}$ を調查した，結果を Table 1 に示すが, 落下累積 1 回の破砕粉だけ検出された。従って不完全 な焼成部分の除去には，鍋焼成物を落下強度試験機で 1 回だけ落下し粉を除去するのが良好と判断された。

また $2 \cdot 2 \cdot 2 て ゙$ 述べたように，落下強度及び回転強度 試験機における試料量ならびに粉の存在の有無は破砕現 象に少なから奴影響を及ほすものと思われる。 そこで, まず落下強度試験機を用いて破砕焼結ケーキから 20 $30 \mathrm{~mm}$ の焼結鉱を篩にて採取し，この焼結鉱 $5 \mathrm{~kg}(20$ $30 \mathrm{~mm}$ 層厚) で焼結鉱層を作成し以下の実験を行った。

焼結鉱層を鉄板上に 1 回だけ落下させた場合と, 鉄 板上に焼結鉱層を形成させこの上に焼結鉱層を落下させ
Table 1. Free carbon content and free $\mathrm{CaO}$ content in sinter fines after shatter test.

\begin{tabular}{c|cccc}
\hline Drop times & 1 & 2 & 3 & 4 \\
\hline Free C (mass\%) & 0.31 & $<0.1$ & $<0.1$ & $<0.1$ \\
Free CaO (mass\%) & 0.62 & $<0.1$ & $<0.1$ & $<0.1$ \\
\hline
\end{tabular}

Table 2. $-5 \mathrm{~mm}$ fines generated at shatter tests with various hearth materials.

\begin{tabular}{c|cccc}
\hline $\begin{array}{c}\text { Hearth } \\
\text { material }\end{array}$ & & $\begin{array}{c}\text { Steel } \\
\text { plate }\end{array}$ & $\begin{array}{c}\text { Sinter particles } \\
\text { of } 20 \text { to } 30 \mathrm{~mm}\end{array}$ & $\begin{array}{c}\text { Sinter } \\
\text { fines }\end{array}$ \\
\hline $\begin{array}{c}\text { Fines } \\
\text { generated }\end{array}$ & $\begin{array}{l}\text { Sinter particles } \\
\text { of } 20 \text { to } 30 \mathrm{~mm} \\
\text { (masth }\end{array}$ & 2.59 & 1.66 & 0.41 \\
Total material & - & 1.09 & - \\
\hline
\end{tabular}

た場合の発生粉率差を調査した。この場合，落下させた 焼結鉱層と鉄板上の焼結鉱層から発生する粉を分離する ため鉄板上の焼結鉱層はビニール袋に入れておいた。さ らに，鉄板上に $-5 \mathrm{~mm}$ 粉（層厚 $30 \mathrm{~mm}$ ）を敷きつめた 上に焼結鉱層を落下させた場合の発生粉率も調查した。 結果を Table 2 に示すが，鉄板上に焼結鉱層を落下さ せた場合が落下焼結鉱から発生する粉率が最も高い。し かし焼結鉱層どおしの衝突の場合，衝突に関与する焼結 鉱量が倍増し両方あわせた発生粉率でほぼ等しい值と なった，粉体上に焼結鉱層を落下させた場合は極端に発 生粉率が小さかった。このような鉄板上敷設の試料差に よる落下焼結釷の発生粉率差は衝突衝撃力の差に起因し ていると思われる。

次に落下強度試験機において，供試量を変更した条件 での発生粉率調査ならびに焼結ケーキにあらかじめ -5 $\mathrm{mm}$ 粉を $22 \%$ 混入させた条件での発生粉率調査を行っ た。ここで混入粉率を $22 \%$ としたが，ケーキ破研実験 における $-5 \mathrm{~mm}$ の発生粉率はほぼ 15 30\%でその中間 值を採用した。結果をFig. 3 に示すが，供試量の影響 は少ないが，混入粉の影響は大きい。回転強度試験機に おいてもほぼ同様の結果が得られた。これは供試量の差 によってたとえ焼結ケーキが鉄板もしくは焼結ケーキと 衝突する確率に差が存在しても, Table 2 の結果に見ら れるごとく発生粉率への影響が小さいためと思われる. 一方, 混入粉の存在により焼結ケーキの発生粉率が低減 するのは焼結ケーキと混入粉との衝突確率が大きくな り，逆に粉発生率の高い焼結ケーキと鉄板または焼結 ケーキどおしの衝突確率が低下するのが主因と思われ る.

従って，粉を除いた焼結ケーキ粒子の破研現象の解析 ならびに評価にあっては, 反復落下強度試験および回転 強度試験における試料量の影響は無視しても良いが発生 粉は出来る限り除去すべきと判断される. 


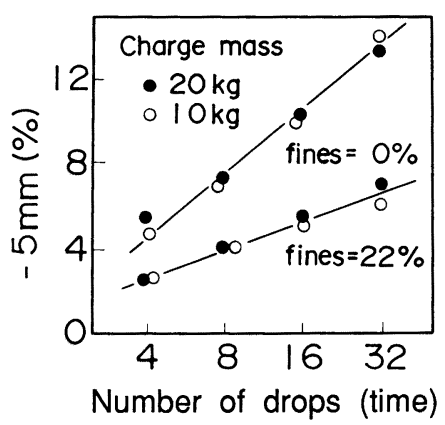

Fig. 3. Difference in generating $-5 \mathrm{~mm}$ fines at shatter test with and without $-5 \mathrm{~mm}$ fines in the starting materials.

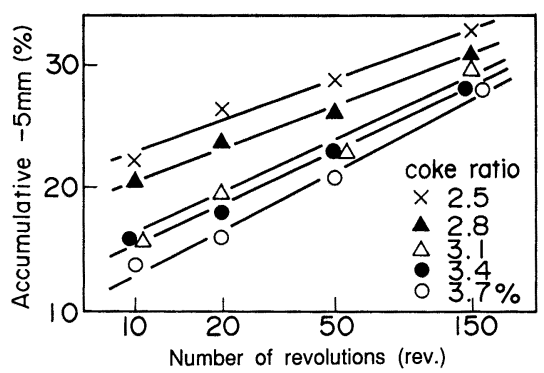

Fig. 4. Accumulative $-5 \mathrm{~mm}$ fines mass $\%$ of cake sintered with various coke ratio of sinter during the tumble test.

\section{$2 \cdot 2$ 実験結果}

$2 \cdot 2 \cdot 1$ 焼成原料のコークス配合量変更テスト

コークス量を変更して製造したケーキにおける落下強 度試験機および回転強度試験機での破砕試験結果は, コークス量の多いほうが発生粉率は低くなった。回転強 度試験機での破砕の途中過程を Fig. 4 に示すが，従来 から指摘されているように年10), 破砕初期段階における 発生粉率が大きく，回転数あたりの発生粉率は累積回転 数の増加とともに低下している.また, 累積回転数の増 加に伴って試料間の発生粉率差が小さくなっている.

コークス量を変更すると焼結ケーキの強度ならびに空 隙構造は大幅に異なる ${ }^{5)}$. 従って, コークス量や回転数 をパラメーターにとって累積発生粉率を記述すると試料 毎に異なった粉率線が得られる。しかし，Fig. 5 に示す ように横軸に $+5 \mathrm{~mm}$ 部分平均粒径をとって累積発生粉 率を整理すれば全試料を狭い帯状の範囲に四示できた。 网から初期形状と破砕方法が一定ならば，焼結ケーキの 空隙構造によらず成品平均粒径が累積発生粉率に対し支 配的な影響力をもつものと理解される.

$2 \cdot 2 \cdot 2$ 焼結ケーキの粒子表面形状および気孔率変化

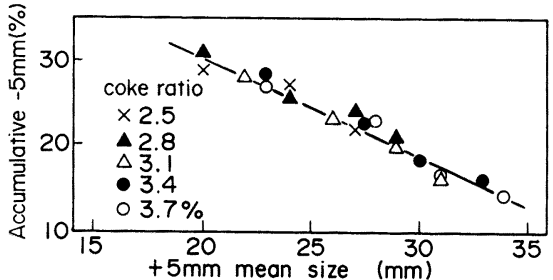

Fig. 5. Relation between mean size of $+5 \mathrm{~mm}$ sinter product and accumulative $-5 \mathrm{~mm}$ fines mass $\%$ of cake sintered with various coke ratio of sinter mix at the tumble test.

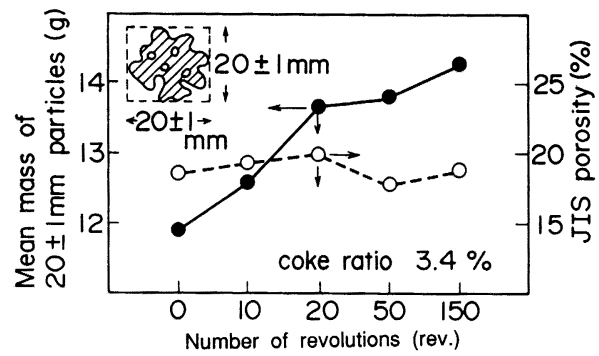

Fig. 6. Change in micro porosity and mass of 19 $21 \mathrm{~mm}$ particles during the tumble test. (Coke ratio of sinter $\operatorname{mix}=3.4 \%$ )

$2 \cdot 2 \cdot 1$ の回転強度試験機破砕（コークス $3.4 \%$ )にお ける粒径 19〜21 mm 粒子の平均質量とミク口気孔率を 測定した結果を Fig. 6 に，粒径 13〜15 mm 粒子のマク 口気孔率，表面山凸度および凸体とみなした円形度を求 めた結果を Fig. 7 に示す。回転破砕中, 気孔率は変化 しないが表面凹凸度は低下する傾向にある。また粒子を 凸体とみなした円形度はわずかであるが上昇し球形に近 づく．一方粒子平均質量は増加する傾向にある。これは 粒子均齐度 (凸体円形度) や粒子見掛密度 (気孔率) に 差が少ないことから粒子表面凹凸度と対応していると考 えられ，画像処理法により求めた結果と整合している. 以上より回転試験機破砕においては，焼結鉱内部の気孔 状態や粒子均斉度の変化は少ないが粒子表面の凹凸はな くなる傾向にある。

$2 \cdot 2 \cdot 3$ 破砕方法変更テスト

3 つの破砕方法の比較として, Fig. 8 には破砕過程に おける成品平均粒径を横軸にとって発生粉率をプロット した. Fig. 9 には平均径が $21 \mathrm{~mm}$ 程度になるまで破砕 した時の全供試料の粒度分布を，Gaudin-Schumann プ

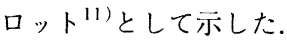

まず Fig. 8 からジョークラッシャーによる破砕は ケーキの粒度低下に際し $-5 \mathrm{~mm}$ 粉発生の少ない破砕力 法であることがわかる.さらに Fig. 9 ではジョークラッ 
シャーによる破砕焼結ケーキの粒度分布が狭いことがわ かる. 従ってジョークラッシャー破砕は焼結ケーキ破砕 における発生粉率ならびに高炉装入物成品の粉度分布の 点から好ましい方法である。

一方，落下強度試験結果と回転強度試験結果を比較す ると Fig. 8 では画方の粉率線が重なり，また Fig. 9 で

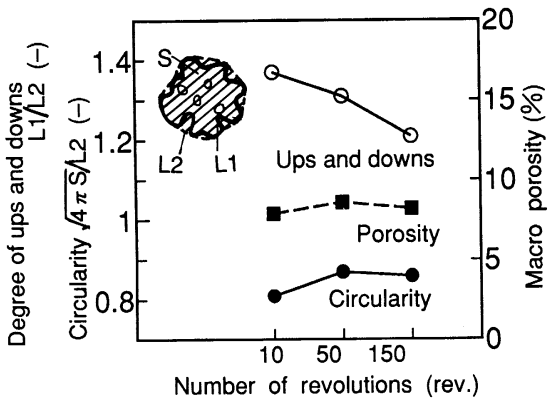

$L 1$ : Peripheral length $L 2$ : Envelope length $S:$ Area enclosed with envelope

Fig. 7. Change in macro porosity, degree of ups and downs on surface and degree of circularity of enveloped particle for $13 \sim 15 \mathrm{~mm}$ particles during the tumble test. (Coke ratio of sinter $\operatorname{mix}=3.4 \%$ )

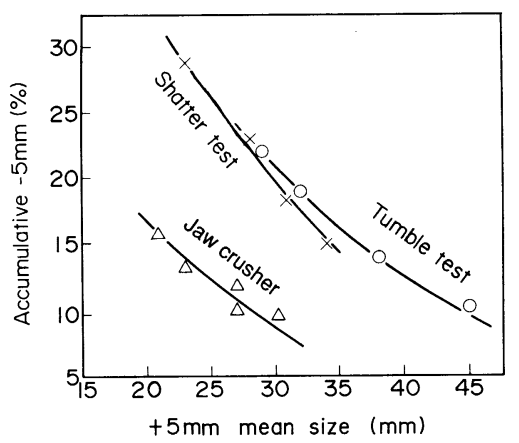

Fig. 8. Effect of crushing mode on the relation between accumulative $-5 \mathrm{~mm}$ fines $\%$ of sinter cake and mean size of sinter product.
は破砕ケーキ粒度分布の一致が認められることから，こ の 2 つが類似の破砕方法であると思われる。この理由 は回転強度試験機ではドラム内に 2 枚のリフターが設 置されており，1回転毎に2 回の落下衝撃が加えられ, 落下衝撃力は異なるものの落下強度試験機と同様の破砕 モードとなっているためと思われる.

\section{$2 \cdot 2 \cdot 4$ ケーキの形状および寸法変更テスト}

川柱または直方体形状ケーキの落下強度試験機破砕に おける発生粉率と成品平均粒径の関係を Fig. 10 に示 す．円柱ケーキは焼結層厚を変更しているのでケーキ空 隙構造は寸法の上昇すなわち高層厚のケーキほど強度的 には強い空隙構造を持っている ${ }^{12)}$ 。一方，直方体ケ一 キでは焼結幅を変更しておりまた強度の弱い上層部を削 除しているので比較的ケーキ空隙構造に差が少ない試料 と思われる。ケーキ寸法が異なれば破砕方法变更結果と 同様に成品粒径と発生粉率の関係が異なる。ここで用い た各ケーキは構造的に同等ではないが， $2 \cdot 2 \cdot 1$ に示され るようにケーキ空隙構造の影響が小さいことを考虑すれ ば，ケーキ寸法そのものが成品粒径-発生粉率の関係を 変化させる要因であると理解される．落下回数をパラ

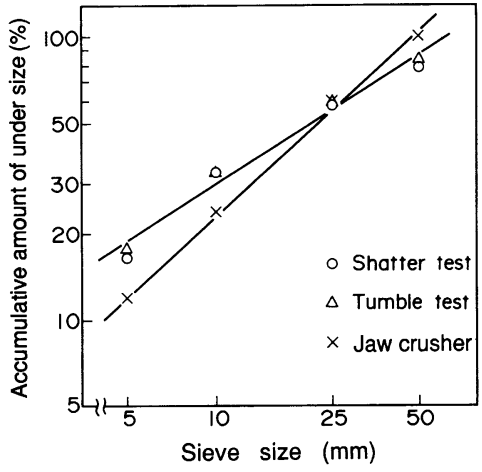

Fig. 9. Size distribution of sinter cakes crushed up to $21 \mathrm{~mm}$ for mean particle size with shatter tester, tumble tester and jaw crusher. (GaudinSchumann plot $^{11)}$.)
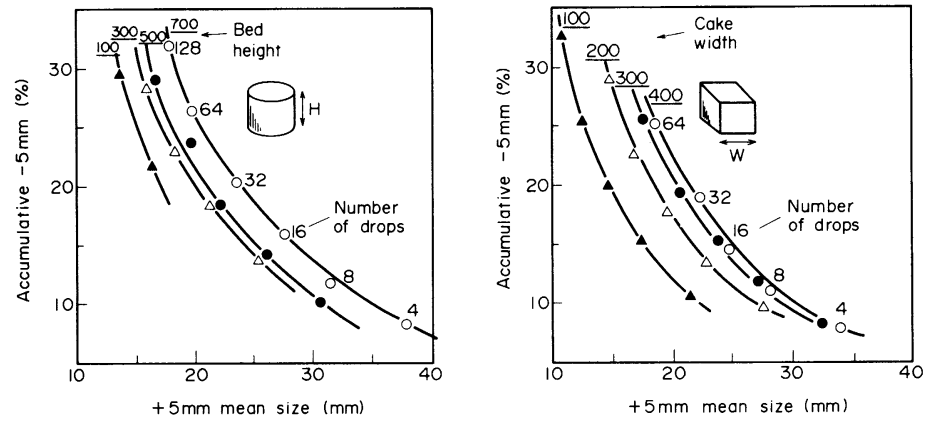

$-127-$
Fig. 10. Relation between mean size of $+5 \mathrm{~mm}$ sinter product and accumulative $-5 \mathrm{~mm}$ fines mass $\%$ of siter cake under varing intial size of siter cake. 
メーターに表示すれば Fig. 11 のようになって, 寸法が 大きなケーキのほうが発生粉率が小さくなる。しかし成 品の平均粒径が高炉側で要求する所定值（例えば 20 mm）になるまでケーキを破砕しなければならないとい う制約を㧍けば，Fig. 10 に示されるように低層厚ある いは幅の狭い，つまり寸法の小さいケーキの方が低粉渄 で目標粒径まで破砕できる結果となっている.

\section{$2 \cdot 3$ 焼結鉱成品粒径と発生粉率に関する考察}

焼結ケーキ粒子の破砕には体積破壞と表面破壊の 2

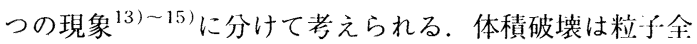
体が複数個の粒径に分かれる現象で，Fig. 10 に見られ るように数回の落下処理により数百 $\mathrm{mm}$ の初期ヶーキ が数十 $\mathrm{mm}$ の粒子に破砕されていることから確認され る。一方，表面破壞は粒子中心部はそのままで外表百部 が分かれる現象で， $2 \cdot 2 \cdot 2$ の結果に見られるように焼結 鉱粒子表面の山凸がなくなる傾向から，粒子表面凸部が

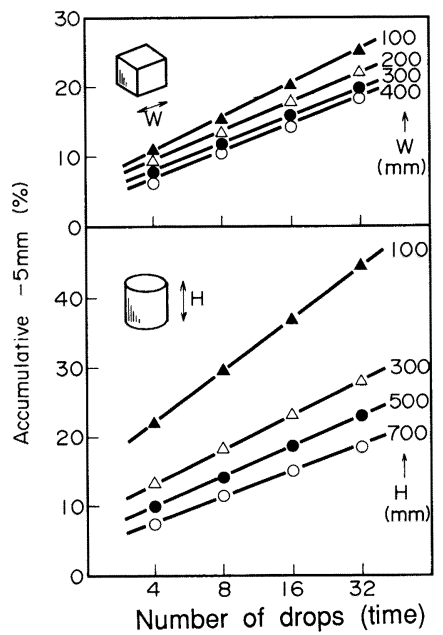

Fig. 11. Accumulative $-5 \mathrm{~mm}$ fines mass $\%$ of sinter cake at the shatter test.
割れ $-5 \mathrm{~mm}$ 粉が発生する表百破壞が起きていることも 理解される.このように笑際の焼結ケーキ破砕にあって は,これら 2 つの破壊現象が混在:して闹時進行するが, 烧結ケーキの表面破壊は体積破壊に比べ成品精径の低下 度令いに対しその発生粉率は多いものと考えられる。

焼結鉱成品の平均粒径を $D$ として，Fig. 10 の実験結 果を横軸に $1 / D$ を選び整理しなおすと, Fig. 12 となり 各条件 (ケーキ寸法, 形状) ごとに㨁線関係が得られる. この結果は $1 / D$ の増分に対忍する発生粉率が一足であ ることを示すが，成品全粒子を平均粒子径の球粒子と似 定すれば $1 / D$ は粒子見掛比表面積（粒子を凸体とみな した状態）に対忍する。すなわち破砕発生粉率は破砕前 後の成怱粒子の見掛比表面積の养に比例した結果となっ ている. 発生粉率と $1 / D$ の関係を示す尚線の傾きを $K$ とすれば，この傾き $K$ は単位見掛比表而積増分当たり の発生粉率と対忍しており，焼結ケーキ破砕において表 面破壊が優勢の時には $K$ は大きな值をとり，体積破壞 が優勢の時には $K$ は小さな优をとる．従って，傾き $K$ は表面破壊と体積破壊の寄与率を示すものと思われる.

このように考えると，衝撃力に対するケーキ全体構造 が弱いと思われる极状の偏平なケーキあるいは棒状の ケーキのほうが立方体のものより体積破壞しゃすく，傾 き $K$ は小さい。また破砕方法においてもジョークラッ シャー破砕の方が体積破壊しやすく，Fig. 8, Fig. 10 に 見られる結果になったものと思われる.

さらに Fig. 12 では初期ケーキ寸法により $1 / D$ と発 生粉率の関係が異なり，2・2・4 で述べたように法が小 さい程同一成品粒径における発生粉率が低い。これは初 期寸法が破砕目標粒径に近い程，破砕にともなう成品粒 度の低下，すなわち粒子見掛比表通積增加の度介いは小 さいので累積される発生粉率も小さくなるためと考え る.
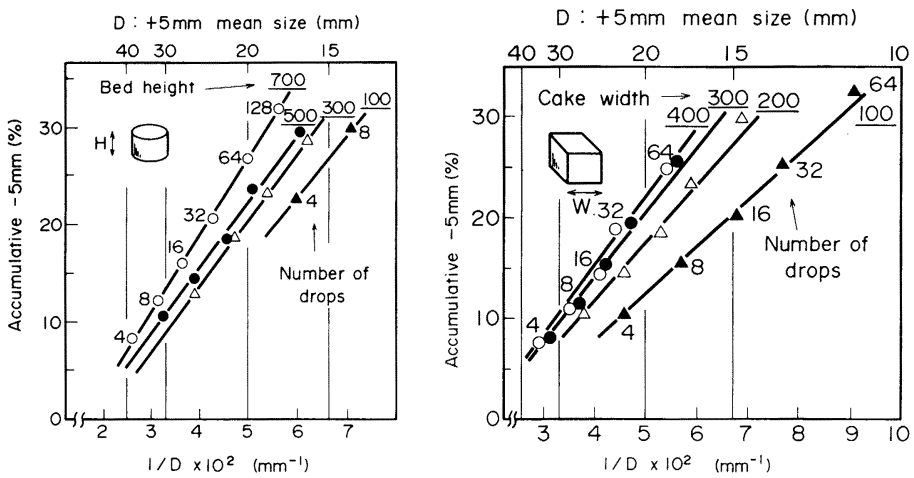

$-128-$
Fig. 12. Relation between reciprocal mean size $1 / D$ of $+5 \mathrm{~mm}$ sinter product and accumulative $-5 \mathrm{~mm}$ fines mass $\%$ of sinter cake under varying initial size of sinter cake. 


\section{3. 実機における焼結ケーキの破砕}

\section{$3 \cdot 1$ 成品粒径と発生粉率}

鹿鼠 No. 2, No. 3 焼結工場および高炉での原料搬送ラ インにおいて破砕焼結ケーキを採取して発生粉率および 成品粒径を調査し，基礎実験で得た知見の検証をおこ なった. 2 つの焼結丁場の操業条件 (コークス比と層厚) は Table 3 に示すように異なっていたが原料条件はほ ぼ同一であったＦig. 13 に発生粉率と成品粒径の関係 を示すが，基礎実験と同様に発生粉率は $1 / D$ に対して 㨁線関係が認められた。また高コークス比で層厚の高い No. 3 焼結-L場の発生粉率線の方が上に位夏しており, 基礎実験の知見と実機調査の結果は整合している.

また実機における傾き $K$ の值を基礎実験結果と比較 したのが Fig. 14 である. 実機の傾き $K$ は，落下衝撃 で破砕した粉率線の傾き $K$ とジョークラッシャ一破砕 した粉率線の傾き $K$ との中間の值を有している．実機 での破砕がクラッシャー（基礎実験とは夕イプが異な る）と落下衝撃で行われていることを考えれば妥当な結 果と思われるが，ジョークラッシャーでの破砕と比較し て実機ではまだ改善の余地が残されていると考える。

\section{$3 \cdot 2$ 焼結ケーキ内強度分布と発生粉率}

和歌山 No. 1 焼結工場において同一原料操業条件で クーラー冷却法とストランド冷却法の比較試験を実施し $た^{16)}$. この時の 1 次クラッシャーの破砕動力と発生粉 率の結果を Table 4 に示す。 ストランド冷却法では破

Table 3. Coke ratio in sinter mix and sinter bed height at No. 2 and No. 3 Kashima Sinter Plants.

\begin{tabular}{ccc}
\hline Sinter plant & No. 2 & No. 3 \\
\hline Coke content $($ mass $\%)$ & 3.13 & 3.33 \\
Bed height $($ mm $)$ & 410 & 520 \\
\hline
\end{tabular}

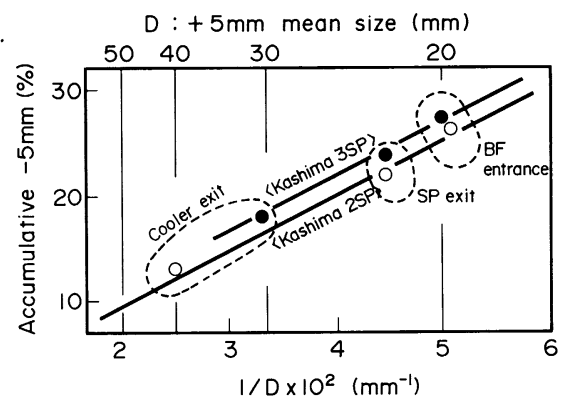

Fig. 13. Relation between reciprocal mean size $1 / D$ of $+5 \mathrm{~mm}$ sinter product and accumulative -5 $\mathrm{mm}$ fines mass\% for sinter cakes at Sinter Plant. (SP) and Blast Furnace (BF) in Kashima steel works.
砕動力の低下と返鉱率の低下が認められる。この差の主 原因として焼結ケーキ内の強度分布差が考えられる。

焼結ケーキにあってはその空隙構造および性質は均一 ではない。一般に焼結化文応時間の差から焼結ケーキ強 度は下層の方が上層より大きい(2)。また冷却法の違い にあっては, クーラー冷却の場合初期破砕においてケ一 キ上層の温度は低いが下層は高温状態で塑性的な性質を 有している。このため鍋焼結下層ケーキの落下強度は常 温では $83.6 \%$ に対し赤熱高温では $93.7 \%$ と高い值を示 し，クーラー冷却の場合は常温の上層と高温の下層では 強度により大きな差が存在する。このような強度分布の 存在するケーキを一律に同一の衝撃を加え目標粒径まで 破砕すると，低強度部分は過粉砕となり成品粒度が小さ くなるとともに発生粉率も高くなるものと考える.

従って, 初期破砕㨁前のケーキ強度の分布はより均一 が望ましく，ストランド冷却法はクーラー冷却法よりも 優れる。またケーキ層厚は低い方が良好と思われる。

\section{4. 考察}

\section{$4 \cdot 1$ 高層厚操業の評価}

従来，歩留改善のためには層厚上昇が効果的とされて

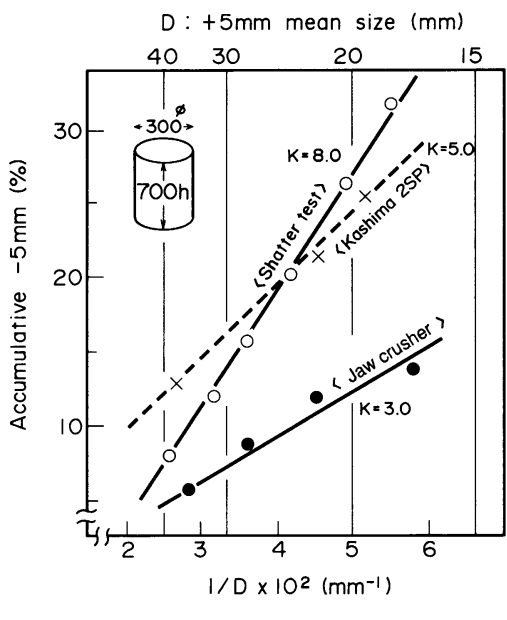

$K$ : Gradient of the lines

Fig. 14. Comparison of crushing efficiency among shatter tester, jaw crusher and sizing system at Kashima No. 2 Sinter Plant.

Table 4. Power of 1 st crusher and return fines ratio for on-strand cooling and off-strand cooling processes at Wakayama No. 1 Sinter Plant.

\begin{tabular}{ccc}
\hline Cooling process & On-strand & Off-strand \\
\hline Electric current of crushing moter $(\mathrm{A})$ & 40 & 60 \\
Return fine(mass\%) & 12.2 & 15.8 \\
\hline
\end{tabular}




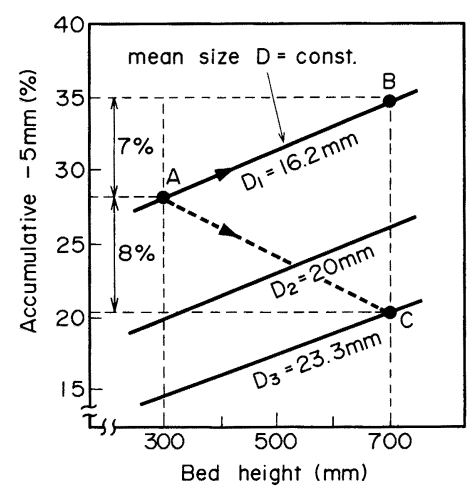

Fig. 15. Relation between accumulative $-5 \mathrm{~mm}$ fines mass $\%$ of sinter cake and height of sinter bed at keeping mean size of $+5 \mathrm{~mm}$ sinter product.

おり ${ }^{12)}$ ，本結果はその知見に一見相反する。そこで Fig. 11 の結果を Fig. 15 に整理した．例えば層厚 300 $\mathrm{mm}$ と $700 \mathrm{~mm}$ のケーキを比較すると, 同じ落下回数 （32回）の時の成品粒径と発生粉率は Fig. 5 の A,C に 示される。この時約 $8 \%$ の発生粉率差が生じ低層厚ヶー キの発生粉率が高い.しかし成品粒径 $(16.2 \mathrm{~mm}$ と $23.3 \mathrm{~mm}$ )にも差が生じている.

そこで成品粒径を $16.2 \mathrm{~mm}$ に一致させようとすれば 層厚 $700 \mathrm{~mm}(\mathrm{C}$ 点 $)$ は, 層厚 $300 \mathrm{~mm}(\mathrm{~A}$ 点 $) に$ に比べて破 砕を強化しなければならず B 点に移行し発生粉率は逆 に $7 \%$ 上昇する。このように, 成品粒径一定か衝撃力一 定かによってケーキ層厚に対する評価は変わる.

実機のように設備が固定されている前提では衝撃力一 定の条件に近く，そのため高層厚ケーキの方が発生粉率 が低下寸ると認識されていたと思われる。この場合成品 粒径の粗粒化を伴っていたと推定される。しかし同一成 品粒径を目標とした衝撃破砕力の異なる設備間で比較す ると, Fig. 13 に示されるように高層厚操業の方が, 発 生粉率が高くなっており必ずしも有利となっていない．

\section{$4 \cdot 2$ 発生粉率低隇への指針}

粉率低隇のための破砕に関する改善策としては，まず 成品粒径の粗粒化が第 1 であり，第 2 に破砕方法を体 積破壊させやすいクラッシャー破砕に傾斜すべきであ る.また焼結ケーキの初期寸法や形状に関しては, 初期 值によらず高炉の要求する成品サイズは $20 \mathrm{~mm}$ 前後で あるから，前述のように高層厚・幅広のケーキほど不利 である。この観点から大型焼結機は歩留の面で多少不利 である．従って第 3 の対策としては，体積破壊しやす い偏平で，最初から目標サイズに近い小さなケーキとな る切れ目をいれておくのが有利と考える.
第 4 にケーキ内の強度分布を均一にし，弱いケーキ の過粉砕を防止する。また目標粒径になった成品は選択 的に抜出し衝撃力を受けないよう配慮すべきである。こ の場合, 発生粉の共存は衝撃破砕力低減に効果がある.

\section{5. 結}

言

鍋ケーキを用いた基礎破砕実験と実機破砕焼結ケーキ のサンプリングから，発生粉率の支配要因を調查し以下 の知見を得た。

（1）破砕方法，ケーキ寸法や形状が一定なら目標とす る成品粒径によって発生粉率は支配される。これはヶ亡 キ強度に依存しない。

（2）破砕方法としては落下や回転強度試験機による破 砕よりもジョークラッシャーによる破砕の方が粉発生の 少ない状態で目標粒径までケーキを破砕できる。

( 3 ) ケーキ寸法は最初から小さく(目標粒径に近い), かつ偏平な形状の方が発生粉の少ない状態で目標粒径ま で破砕できる。

(4)目標成品粒径まで同一衝撃履歴によって全ケーキ を破砕するものとすれば，ケーキ内の強度分布が均一で ある方が発生粉率が低隇すると考えられる。

\section{文献}

1 ) T. Inazumi, S. Kasama, K. Sato and N. Tanaka: Proc. 5th International symp. on agglomeration, Brighton England, (1989), p. 599

2 ) 稲角忠弘, 笠間俊次, 藤本政美, 佐藤勝彦: 材料とプロセ ス, 3 (1990), p. 968

3 ) 八嶋三郎, 橋本 等: 材料とプロセス, 3 (1990), p. 948

4 ) 中島龍一, 谷中秀臣, 服部道紀, 小松 修, 長野誠規, 高木 昭: 鉄と鋼, 72 (1986), S802

5 ) 暮西栄輝, R. R. Lovel, W. J. Rankin, 大森康男: 鉄と鋼, 75 (1989), p. 228

6 ）佐藤 駿, 川口尊三, 一伊達 稔, 吉永真弓: 鉄と鋼, 73 (1987), p. 48

7 ) 森 芳郎: 化学工学便覽改言 3 版 (化学工学協会編), p. 1021 [丸善]

8 ) 佐藤 駿, 川口尊三，一伊達 稔，吉永真与: 鉄と鋼, 73 (1987), p. 54

9 ) 城 博, 井田四郎: 製鉄研究 (1966) 254, p. 6331

10）和島英明: 鉄と鋼, 73 (1987), S99

11) R. Schumann: Am. Inst. Min. Met. Eng. Tech., Pub. (1940), p. 1189

12) I. Shimizu, M. Yoshinaga, K. Monji and T. Funabashi: Proc. ICSTIS (1976), Section 1, p. 83

13) D. Jeulin: Ironmaking Steelmaking, 10 (1983), p. 145

14）森 芳郎, 神保元二: 化学工学, 23 (1959), p. 138

15) A. G. Waters, A. Vince and J. D. Litster : 14 th Australian Chemical Engineering Conference (1986)

16）日本鉄鋼協会共同研究会製鉄部会鉄 63-13- 自 (1983) (私信) 